〔農村医学 23巻1号 20２6頁 昭. 49.2〕

\title{
佐久総合病院後腹膜科 (泌尿器科)
}

\section{の 診 療 活 動 報 告}

\section{藤田公生"}

\section{粕}

\section{흠}

筆者が传久総合病院に赴任し，後腹膜科の別称のも とに泌尿器科診療を独立して担当するようになった 1972 年 7 月 1 日から 1973 年 6 月 30 日までの 1 年間に, 1,110 名の患者が当科を受診した。これらの患者をみ ていると, 泌尿器科の現状が住民たちにも他科の医師 たちにも充分に理解されていないことが痛感される。 ここに 1 年間の掺療活動を報告するとともに，そのな かからいくつかの問題点をとりあげて述べてみたい。

\section{対象と方 法}

当科が診療を開始した 1972 年 7 月 1 日から 1973 年 6 月 30 日までに当科を受診した新来患者を対象とした。

疾患分類は WHO の死因統計分類の第 8 回修正 $(1965$ 年）をもとにして厚生統計協議会第四部会で検討した ものを用いた。

疾患分類であるので，同一人に各々独立した疾患の あるときはそれぞれを別の疾患としてとりあげた。例 えば前立腺肥大症と督盅胞といった場合である。この ために疾患数は 1,110 より多くなっている。ふたつの 疾患の間に多少でも因果関係のあることが考えられた 場合は，原因疾患と思われる疾患のみをとりあげた。 例えば尿管結石とそのための水督症は尿管結石，腎杯

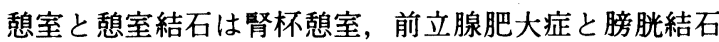
は前立腺肥大症といったぐあいである。

ただし泌尿器科的な観点からみた集計であるので， 他科疾患が原因で泌尿器科的疾患をまねいたときは後 者をとつた。つまり子宮癌患者が放射線治療を受け， のちに放射線膀腅炎を起したときは放射線治療による 障害であり，癌の尿管浸潤によって水腎症をまねいた ときは続発性腫瘍というようになる。子宮癌患者が当 科に紹介されて検索を行ない, 泌尿器科的異常のみら

*長野県 佐久総合病院後腹膜科（泌尿器科）医長 受付：昭和 48 年 7 月 28 日
れなかった場合は，医療の必要のない所見，明示され たものに分類した。

なお，項目名は実際にあった症例に則して一部に変 更を加えてある。

䊅

果

月別の新来患者数を図 1 に示した。女性の受診者は 年間を通じてほぼ一定であるが，男性は農繁期である 4 月および $9,10,11$ 月に少ない。

図1月別新来患者数

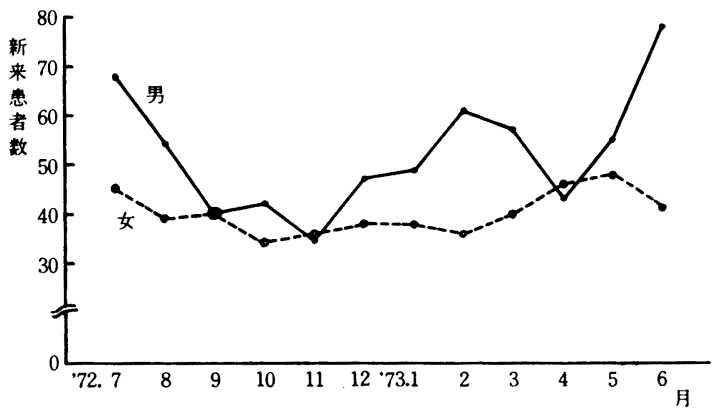

図 2 は年令別の分布である。10 才未満の男子が多い のは停留殬丸, 尿道下裂, 包茎と包皮炎などの奇型が

図 2 年 令 別 分 布

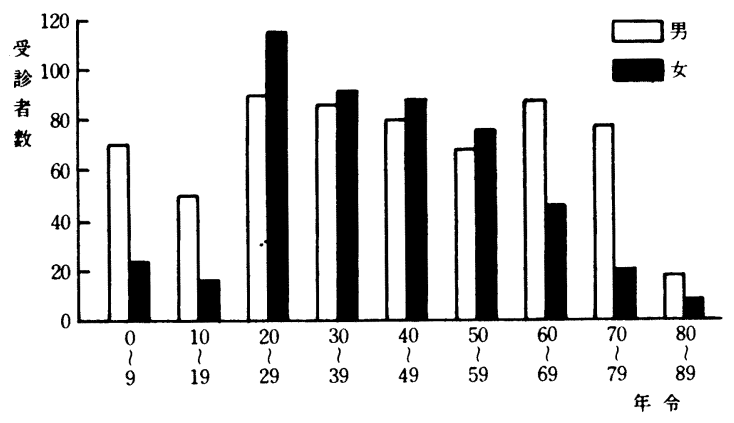


主であり, 高令男性は大部分が前立腺肥大症ないしそ れに準ずる疾患であり，20から50才代の女性に多い 疾患は膀胱炎である。

図 3 は受診者を地域別にわけ，さらに人口あたりの 比をとったものである。当然佐久総合病院の診療圈と ほぼ一致するが，それよりも多少拡がりをみせている。

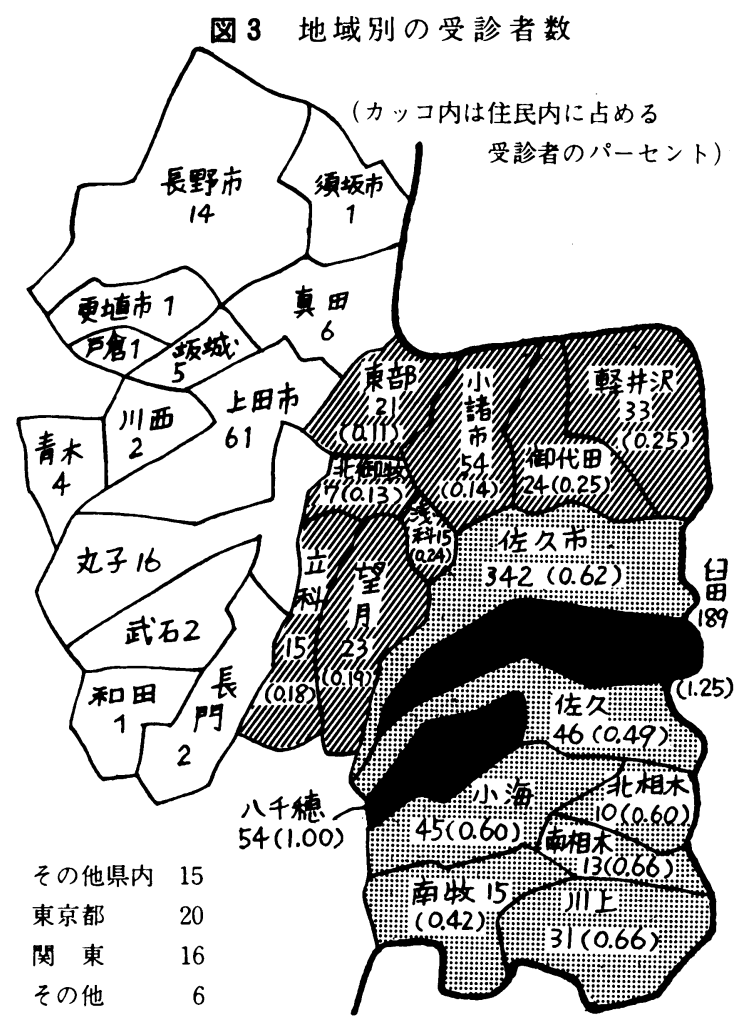

なお泌尿器科専門医のいる，当院にもっとも近い病院

は，東は高崎市，西は長野市にある。

以下，疾患表に従って補足説明を行なう（表 1$) 。$

表 1 疾 患 分 類 表

\begin{tabular}{c|c|c|c|c}
\hline 番 号 & 疾 患 & 男 & 女 & 計
\end{tabular}

I．伝染病および奇生虫病

\begin{tabular}{c|r|r|r|l}
\hline \multicolumn{2}{|c|}{ 結 核 } & 17 & 14 & 31 \\
016 & 8 & 5 & 13 \\
019.2 & 尿性器系の結核 & 9 & 9 & 18 \\
梅 毒 & 5 & 1 & 6. \\
091.0 & 第一期梅毒 & 2 & 0 & 2 \\
092.0 & 早期梅毒治潦後の血清反応陽性 & 1 & 0 & 1 \\
097.1 & 2 & 1 & 3 \\
淋 詳細不明の潜伏梅毒 & 5 & 0 & 5 \\
098.0 & 急性性尿路淋菌感染 & 5 & 0 & 5
\end{tabular}

II. 新 生 物

\begin{tabular}{|c|c|c|c|c|c|}
\hline \multicolumn{3}{|c|}{ 悪性新生物 } & 47 & 7 & 54 \\
\hline 185 & \multicolumn{2}{|c|}{ 前立腺の悪性新生物 } & 22 & 0 & 22 \\
\hline 186 & 幸丸の & " & 3 & 0 & 3 \\
\hline 188 & 膀胱の & " & 17 & 3 & 20 \\
\hline 189.1 & 腎孟の & " & 3 & 0 & 3 \\
\hline 198 & 泌尿器 0 & 飞性" & 2 & 4 & 6 \\
\hline \multicolumn{3}{|c|}{ 良性ないし性質不詳の新生物 } & 14 & 2 & 16 \\
\hline 215 & \multicolumn{2}{|c|}{ 筋および結合織の良性新生物 } & 0 & ** & 1 \\
\hline 222.1 & 陰荎の & " & 6 & 0 & 6 \\
\hline 2 & 副昱丸 & " & 1 & 0 & 1 \\
\hline 223.0 & \multicolumn{2}{|c|}{ 腎の良性新生物 } & 1 & 0 & 1 \\
\hline 2 & \multicolumn{2}{|c|}{ 尿管の " } & 1 & 0 & 1 \\
\hline 237.2 & \multicolumn{2}{|c|}{ 副殬丸の性質不詳の新生物 } & 5 & 0 & 5 \\
\hline 6 & \multicolumn{2}{|l|}{ 膀胱の } & 0 & 1 & 1 \\
\hline
\end{tabular}

*うち 1 例は前立腺平滑筋肉腫

**督洞部に発生した angiomyolipoma

\begin{tabular}{c|c|c|c|c}
\cline { 3 - 5 } VI. 循環器系の疾患 & 1 & 1 & 2 \\
\hline 433.3 & 督動脈塞栓 & 0 & 1 & 1 \\
456.1 & 精卖静脈瘤 & 1 & 0 & 1
\end{tabular}

$X$. 性尿器系の疾患

\begin{tabular}{|c|c|c|c|c|}
\hline \multicolumn{2}{|c|}{ 腎炎およびネフローゼ } & 5 & 5 & 10 \\
\hline 580 & 急性腎炎 & 0 & 1 & \\
\hline 581 & ネフローゼ症候群 & 2 & 0 & 2 \\
\hline 582 & 慢性腎炎 & 2 & 4 & \\
\hline 584 & 性質不明の腎の萎縮 & 1 & 0 & \\
\hline \multicolumn{2}{|c|}{ その他の泌尿器系の疾患 } & 369 & 317 & 676 \\
\hline 590.0 & (膀胼尿管逆流による)慢性督督肾炎 & 0 & 3 & \\
\hline 1 & その他の腎孟腎炎 & 7 & 8 & 15 \\
\hline 591 & 水腎症 & 5 & 7 & 12 \\
\hline 592 & 腎および尿管の結石 & 40 & 25 & 6 \\
\hline 593.2 & 遊走腎 & 1 & 22 & 2 \\
\hline 4 & 水尿管症 & 3 & 0 & \\
\hline 5 & その他の尿管の疾患 & 1 & 1 & \\
\hline 594 & 膀胱結石 & 2 & 0 & \\
\hline 595 & 膀胱炎 & 21 & 232 & 253 \\
\hline \multirow[t]{2}{*}{596} & 膀胱覣室 & 0 & 3 & \\
\hline & 膀胱頸部狭窄 & 0 & 2 & \\
\hline 597 & 尿道炎（非性病性） & 3 & 6 & \\
\hline 598 & 尿道狭窄 & 5 & 0 & \\
\hline 599 & 尿道カルンクラ & 0 & 7 & \\
\hline 600 & 前立腺肥大症 & 95 & 0 & 95 \\
\hline 601 & 前立腺炎 & 34 & 0 & 34 \\
\hline \multirow[t]{3}{*}{602} & 前立腺症 & 4 & 0 & \\
\hline & 前立腺結石 & *** & 0 & \\
\hline & 膀胱頸部硬化症 & 36 & 0 & \\
\hline \multirow[t]{2}{*}{603} & 陰軎水瘤 & 18 & 0 & 18 \\
\hline & 精索水瘤 & 1 & 0 & \\
\hline 604 & 副睪丸炎 & 12 & 0 & 1 \\
\hline
\end{tabular}




\begin{tabular}{|c|c|c|c|c|}
\hline 605 & 過長包皮および包茎 & 31 & 0 & 31 \\
\hline 606 & 男性不妊症 & 9 & 0 & 9 \\
\hline 607.0 & 陰荎硬結 & 2 & 0 & 2 \\
\hline 2 & " 慢性潰瘍 & 2 & 0 & 2 \\
\hline 3 & 粕頭包皮炎 & 17 & 0 & 17 \\
\hline 4 & 精軎炎 & 7 & 0 & 7 \\
\hline 7 & 鋅丸捻転 & 1 & 0 & 1 \\
\hline \multirow[t]{2}{*}{9} & 陰茎屈曲 & 1 & 0 & 1 \\
\hline & 尖圭コンジローマ & 3 & 0 & 3 \\
\hline 623.2 & 尿道脱 & 0 & 1 & 1 \\
\hline
\end{tabular}

\begin{tabular}{c|l|r|r|r}
\multicolumn{2}{c}{ XII. 皮ふおよ゙゙皮下組織の疾患 } & 12 & 0 & 12 \\
\hline 692.3 & 薬物による皮ふ炎 & 4 & 0 & 4 \\
9 & 原因不明の湿疹 & 6 & 0 & 6 \\
697.0 & 扁平苔癖 & 1 & 0 & 1 \\
709 & 白 斑 & 1 & 0 & 1
\end{tabular}

\begin{tabular}{|c|c|c|c|c|}
\hline \multicolumn{2}{|c|}{ XIV. 先 天 異 常 } & 29 & 16 & 45 \\
\hline 752.1 & 停留睪丸 & 12 & 0 & 12 \\
\hline 2 & 尿道下裂 & 2 & $\stackrel{*}{1}$ & 3 \\
\hline 753.1 & 多発性輬胞腎 & 0 & 5 & 5 \\
\hline & 腎輁胞 & 4 & 0 & 4 \\
\hline 3 & 海綿腎 & 1 & 3 & 4 \\
\hline & 腎杯䡯室 & 0 & 1 & 1 \\
\hline & 腎の回転異常 & 1 & 2 & 3 \\
\hline 4 & 重複尿管 & 6 & 3 & 9 \\
\hline 6 & 先天性尿道弁 & 1 & 0 & 1 \\
\hline 759.5 & 性染色体異常 & ${ }^{* *}$ & $\stackrel{1}{* * * *}$ & 3 \\
\hline
\end{tabular}

*女子尿道下裂の病的意義が最近いわれている

** Klinefelter 症候群

***Turner 症候群

NXVII．不虑の事故，中毒および暴力

\begin{tabular}{|c|c|c|c|c|}
\hline & & & & \\
\hline N866 & 腎の損傷 & 0 & 1 & 1 \\
\hline \multirow[t]{2}{*}{ N867 } & 膀胱 " & 1 & 1 & 2 \\
\hline & 尿道 " & 1 & 0 & 1 \\
\hline \multirow[t]{3}{*}{ N878 } & 陰茎 " & 4 & 0 & 4 \\
\hline & 箁丸" & 1 & 0 & 1 \\
\hline & 陰㐮" & 2 & 0 & 2 \\
\hline \multirow[t]{2}{*}{ N939 } & 会陰異物 & 1 & 0 & 1 \\
\hline & 尿道 " & 1 & 0 & 1 \\
\hline N958.9 & 神経因性膀胱 & 16 & 2 & 18 \\
\hline N990 & 放射線による膀胱炎 & 0 & 1 & 1 \\
\hline N998.4 & 膀胱内にかかった絹系 & 0 & 1 & 1 \\
\hline
\end{tabular}

V. 精神障害 XVI. 症状および診断名不明確等

\begin{tabular}{l|l|r|r|r}
\multicolumn{2}{c}{ の状息 } & 126 & 114 & 240 \\
\hline 305.6 & 心因性と推定される性尿器障害 & 6 & 0 & 6 \\
306.6 & 遗尿症 & 11 & 11 & 22
\end{tabular}

\begin{tabular}{|c|c|c|c|}
\hline 786.0 & 性尿器に関する痤痛 & 5 & 1 \\
\hline 1 & 尿閉，排尿障害 & 3 & 0 \\
\hline 2 & 尿失禁 (急迫尿失禁をふくめ) & 1 & 6 \\
\hline 3 & 頻 尿 & 12 & 7 \\
\hline 5 & 乏尿, 無尿 & 1 & 0 \\
\hline & 陰 萎 & 3 & 0 \\
\hline 789.0 & 蛋白尿 & 2 & 0 \\
\hline 3 & 血 尿 & 14 & 7 \\
\hline 4 & ヘモグロビン尿 & 1 & 0 \\
\hline 793.0 & 医療の必要のない所見, 精神的なもの & 20 & 15 \\
\hline 8 & $\begin{array}{l}\text { 明確な他科疾患をもつもの } \\
\text { 健康相談的なもの }\end{array}$ & $\begin{array}{r}7 \\
23\end{array}$ & $\begin{array}{r}31 \\
9\end{array}$ \\
\hline 796 & 診断不明確な腰痛, 腹痛 & 17 & 27 \\
\hline
\end{tabular}

早期梅毒例は，筆者は10 年近く東京で診療にたずさ わっていて，1例もみたことがなかった。淋疾をふく めて, ほとんどの例が農協組織の東南アジア方面への 団体旅行の結果である。

前立腺肉腫の 1 例は, いくつかの問題点とともに原 著として報告した。尿路の乳頭状腫瘍は Grade に関係 なく悪性新生物に分類した。

腎炎およびネフローゼの症例には，堅生検を依頼さ れて受診したものも尿の異常を主訴として当科を受診 したものもふくまれている。なお人工透析の患者は, 筆者はその責任者になっているが，このなかにはふく まれていない。

水腎症や結石は，すでに述べたように，あきらかに 他の原因の認められた例は除いてある。従って実際に 水腎症や尿路結石のみられた症例はこれよりも多い。 この 12 例の水腎症症例の多くは腎孟尿管移行部の狭窄 であり，疾患の性格としては先天性異常に分類される べきものである。膀胱炎もあきらかな基礎疾患のある ものは除いたので, 男性の場合は急性出血性膀胱炎の 占める割合が大きい。前立腺炎は広義に, prostatosis などといわれているものもふくめてある。精襄炎も同 様に，血精液症で腫瘤などの触れないものをすべてふ くめた。

腎の糞胞性疾患がすべて先天異常と解せられるかど うか疑問であるが, polycystic kidney 以外の腎囊胞を, parapelvic cyst をふくめて, 一括した。なお先天性陰 囊水瘤という分類項目があったが，今回の集計では乳 児例もすべて泌尿器疾患のなかの陰串水瘤の項にふく めた。

神経因性膀胱を分類すべき項目がみあたらなかった ので背能道損傷の後遺症に一括したが，すべてが脊娟道損 傷によるものではない。 
手術に伴う事故として, 子宮手術の際に縫合に使用 した綟禾が膀胱内腔にかかり，長い間慢性膀胱炎とし て治療を受けていた例があった。この例は内視鏡的に 綟禾を除去した。

はっきりした疾患をもたない例については次のよう に分類した。以前膀胱炎を起したことがあるとか, 蛋 白尿があるといわれたという例，あるいは精管結紫の 相談などは健康相談的なものという項を設けた。多彩 かつ不定な症状を訴えるいわゆる syphilophobia 的なも ので， 1 回ないし数回の説明で納得したものは精神的 なものという項に分類し，それ以上のものは心因性と 推定される障害に分類した。

表 2 に，患者数の多かった疾患を集めてみた。

表 2 十大疾患一覧

\begin{tabular}{|c|c|c|c|}
\hline 疾 & 男 & 女 & 計 \\
\hline 1. 膀胱炎 & 21 & 231 & 252 \\
\hline 2. 前立腺肥大症 & 95 & 0 & 95 \\
\hline 3. 上部尿路結石 & 40 & 25 & 65 \\
\hline 4. 前立腺炎 & 34 & 0 & 34 \\
\hline 5. 過長包皮および包荎 & 31 & 0 & 31 \\
\hline 6 . 結 核 & 17 & 14 & 31 \\
\hline 7. 遊走㫮 & 1 & 22 & 23 \\
\hline 8. 遗尿症 & 11 & 11 & 22 \\
\hline 9. 前立腺癌 & 21 & 0 & 21 \\
\hline 10. 膀胱癌 & 17 & 3 & 20 \\
\hline 全 患 者 数 & 628 & 482 & 1,110 \\
\hline
\end{tabular}

\section{考按}

当科のもっている性格は, 院内他科からの紹介 346 例, $31.2 \%$, 院外の医師の紹介 71 例, $6.4 \%$ という数 字に如実に示されている。当科を受診する患者の少な くとも 3 人に 1 人は他の医師に紹介されて受診してい るのである。いわば 2 大疾患とでもいうべき男性の前 立腺肥大症と女性の膀腅炎を除けば，この傾向はより 顕著になる。つまり泌尿器科の患者は腹痛や発熱など の不定な症状をもって発症することが多く, 泌尿器疾 患だと最初から認識して受診してくることが少ないの である。また，他の疾患に尿路障害を合併する場合も 多い。紹介されずに受診した患者のなかにも，他医で 治療を続けて思わしくないので当科を受診してきた例 が多い。

従って, 泌尿器科医は他科の医師に対してコンサル タントとしての立場をとる機会が多い。また逆の見方
をすれば，泌尿器疾患が一般医によって不充分な診断 や不適切な治療を受けてすまされていることが多いと いうことになる。筆者が筆をとった理由はここにある のであって, 本稿は泌尿器科専門医ではなく, むしろ 農村の第一線において診療を行なっている多くのひと びとに読んで頂きたいのである。

\section{国際疾病分類について}

泌尿器科領域においてはしばしば外来統計, 入院統 計ないし手術統計が行なわれているのであるが，各人 各様の分類方式が行なわれている。

International Classification of Disease は疾患分類 にも使えるように修正されたとはいえ，本来は死因統 計から出発したものであり, とくに泌尿器科のように 専門的に分化した領域においては，大分類の項目をみ ても個々の疾患に対する分析ないし認識をみても，も のたりない感がするのは事実である。しかし，たがい の意志を通じさせるには共通な言語が必要なように, 相互の資料を比較するには共通な集計方法がとられな ければならない。不備な部分は細分類で補足修正する ことにして、このような疾患統計には本分類法を有効 に活用する努力がなされるべきであろう。

\section{膀 胱 炎}

単純な膀胱炎はほとんどがサルファ剂程度の内服で 数日で治虑するものであり,もし治癒しなければ結石 その他の器質的疾患を疑ったほうがよい。いたずらに 強力な抗生物質や消炎剤の投与を重ねるのは有害無益 というほかはない。

異常所見の判定もできない検査をみだりに行なうの も考えもので，他医で治療を受けていたがよくならな いといって受診する患者のなかには, 腎孟造影や膀腅 鏡検査が行なわれ，しかも大切な所見が見落されてい る例がときどきある。以前に検査してもらってなんと もないといわれたからとか, 検査が痛かったからとい う患者を納得させながら再検するのは, 前医を非難す るわけにもいかず困惑することが多い。このような投 薬や検査はいたずらに医療費の增大をまねき，患者に 直接に肉体的および経済的負担を与えて苦しめること になる。

事実, 慢然と慢性膀胱炎として長期間治療されてい た結核患者が数例あり，また，尿管カテーテル法を行 ないながら結石の存在に気づかれなかった例，DIP まで やって腎孟の拡張を認めながらその原因である結石を 見落して，半年後に当科を受診したときは該腎の機能 廃絶寸前だったという類いの例は枚挙にいとまがない。 
結 核

二次結核としての尿路結核は, 全体的な結核患者の 減少とともに減少し, 昭和 30 年までは泌尿器科外来患 者の約 $10 \%$ だったのが昭和 40 年頃は $2 \sim 3 \%$ ，そし て昨今では $1 \%$ 前後に減少している。

減少の傾向をみせているとはいえ，今日においても 結核が重要な疾患であることには変りないのであって， ここで特に注意を喚起したいことは，尿路結核は膀胱 症状をもって発症するという古いことばである。前項 に述べたように，きちんとした鑑別がなされないまま にただの尿路感染症として治療されている例が，現在 もなお多いのではないかということは，筆者の経験か らも想像される。

\section{尿路結石}

上部尿路結石が 65 例みられているが, このうち手術 の行なわれたのは 6 例にすぎない。尿管結石のほとん どの例は自然排出を待ち; 一部は内視鏡的なバスケッ トカテーテル操作で処理されている。痛い結石ほど手 術の必要はないということができる。尿路結石は疾患 の性質上，再発することが多いので，なるべく手術を 行なわないことか望ましく，手術を行なう場合は再手 術の可能性を考虑しながら行なうべきである。

腎をはじめとする後腹膜臓器は身体の深部にあって 前方は腹腔蔵器, 後方は背柱と背筋群でおおわれてお り，どこからアプローチするにしても到達の困難な位 置である。腰部斜切開による腹膜外からの腎への到達 法は代表的なものであるが, 筋層からの出血や術後の 疼痛などの欠点があり, 視野も必ずしも良好なもので はなく, 症例に応じて種々な到達法が選ばれる。腎孟 ないし上部尿管結石に対しては最近上述のような理由 で背部垂直切開が賞用されるようになり, 筆者ももつ ぱらこれを用いている。

抗生物質の発達, 手術手技の進歩によって腎切石, 腎部分切除など腎実質に大胆にメスをいれる手術が行 なわれるようになってきたが，他方では腎実質になる ベく障害を与えないように，また再手術がやりやすい ようにという目的で, 腎孟腎杯切石術のような手技も 発達してきている。

一般外科医が切石術を行なうと手術部位に狭窄をき たして水腎症になることが多い。尿管結石はなるべく 手術をしないこと, 手術を行なうときは剥離を最少限 度にすること，切石部位に狭窄をきたさないことが基 本方針であろう。

尿路閉塞性の腎不全
尿路閉塞による水督症そして督不全，別のことばで いえば瞥後性腎不全について述べてみたい。これが意 外に理解してもらえない概念なのである。

この典型的な例は子宮癌患者においてしばしばみら れる。 まず 1 側の尿管に狭窄のきたとき側腹部に鈍痛 がくるが，あまり気にされない。そのうち他焣にも狭 窄がおよび水堅症が進行するが, この時期は，尿量は むしろ增加の傾向をみせる。血中尿素窒素值は徐々に 上昇する。やがて急速な尿量の減少と尿毒症が起きて 死亡する。

この病態が理解されないために，例えば 1 日 $500 \mathrm{~m} \ell$ 以上の尿量があるのになぜ閉塞性の疾患なのだと反問 されることがある。本当に閉塞性の督不全ならもっと 尿量が減ってよいはずだというのである。しかし，こ れはまったく逆なのである。通常の呰ならば，尿量

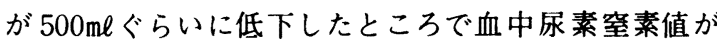
上昇するはずがない。これだけの尿があるにかかわら ず血中尿素窒素值が上昇してきているのは, その腎が まともでない証拠である。つまり長期にわたる尿路の 閉塞が腎実質を圧迫して, 薄い, 低比重の尿しか出て いない証拠なのである。このような患者は閉塞を解除 してやるのが最良かつ劇的な治療法になる, 姑息的に 人工透析などを行なって時を延ばせば回復すべき堅も 回復しなくなる。

近年急速に進展をみせた水電解質および腎機能に関 する知識も，透析に関係している医師など一部を除く と，まだ広く理解されていないように思われる。

\section{経尿道的切除術}

Transurethral resection (TUR) は切除鏡を用いて 内視鏡的に電気切除および止血凝固を行なうもので, 比較的近年，とくにアメリカにおいて大いに発展した。 内視鏡的操作は他科においてもファイバースコープの 開発をはじめとする工学分野の進歩とともに, 最近か なりの進歩をみせているが，本法は内視鏡の歴史とと もに歩んできた泌尿器科の到達したひとつの高峰とい えるだろう。

本法は open surgeryにくらべて手術侵慗が少なく, 高令者に多い前立腺肥大症, あるいは前立腺肥大症様 の症状を示しながら前立腺は肥大していない膀胱頸部 硬化症には非常によい適応になる。その他にも浅筋層 までの膀腅腫瘍, 神経因性膀腅において頸部の抵抗を 相対的に低下させるための切除など適応の範囲は広い。

穿孔, 大出血, いわゆる TUR 反応など合併症の起 ることも多く，高度な技術が要求され，わが国におい てはまだ允分にひろまっているとはいい難いが, 今後 
広く普及していく方法であろう。Cryosurgeryも同様 な内視鏡的手技を用いて試みられているが，いろいろ 欠点があるために，電気切除の方が全体的にみたとき 優れた方法のようである。

\section{終りに}

ひとつのクリニックとして年間の新患数が 1,110 名 というのは特に多いわけではないが, ひとりの泌尿器 科医が本当にひとりで診察し診断し治療したという経 験は少ないことであろう。これは一方では筆者に課せ られた責任が重いことを意味し，しばしば陷りがちな 独善に注意しなければならない。疾患内容としては東 京をはじめ都市部の病院における集計とほぼ同一であ る。

当科を受診した患者は一連番号で登録され，10 年, 20 年という長い観点から治療方針が決められる。大学 病院や，大学から派遗された医師によって運営される いわゆる関連病院においては, 患者の長い一生が考虑 されるというよりは，一時的などちらかといえば派手 な手術が行なわれる傾向がある。しかし，当院のよう に閉鎖された地方で長く診療活動を続けていくつもり であれば，一時を糊㙦するような治療は許されない。

この 1 年間の診療をふりかえると，いかに泌尿器科 疾患に対する一般の認識が少ないかということが痛感 される。これを解決するには一般住民に対しては啓蒙 活動と積極的なスクリーニング，他の医療従事者に対 しては個々の症例を通じての説明とともに，機会をと らえてはこのように理解を梁めて頂く努力をすること が必要と思われたので, この 1 年間の総括を報告し た。

\section{結}

語

佐久総合病院後腹膜科 (泌尿器科) 1972 年 7 月か ら 1973 年 6 月までの 1 年間に受診した患者の集計を 行なった。

男性 628 名，女性 482 名，計 1,110 名が受診した。 男性の受診者は農繁期に減少する傾向がみられた。

膀胱炎, 前立腺肥大症, 尿路結石が三大疾患であっ た。前立腺癌, 膀胱癌もかなりの数を占めた。これは 都会における疾患像とほぼ同一である。

農村医療の第一線に立つひとびとに理解してもらい たいいくつかの問題点をとりあげて述べた。

稿を終えるにあたり，理想的なチームワークのもとにこの 1 年 間の診㙩活動をともにした深海澄子，楜沢百子両ナースに感謝す る。

また，ただひとりの泌尿器科医を陰に陽に扶けて協力してくれ た外科の諸先生はじめ佐久総合病院の全従業員に謝意を表する。

\section{文}

1) 厚生省編：死亡診断書, 死産証書, 出生証明書の書きかた。 疾病, 第害, 死因統計分類. 厚生統計協会, 東京, 1968.

2）藤田公生：前立腺平滑筋肉腫. 日泌尿会誌，64：408-411, 1973.

3）藤田公生：Parapelvic space occupying lesion. 臨放, 投稿 中.

4）仁平宽巳：尿路結核の現況. 西日泌尿, 34:110-112, 1972.

5）堀内誠三：督結石に関する手術：督孟切石術と督切石術，臨 泌, $27: 453-464,1973$.

6）藤田公生，中内浩二，松本恵一：呰瘦ないし尿管瘦術を行な った子宮頸癌患者65例の経験. 外科, $32: 1247-1250,1970$.

7）藤田公生, 中内浩二, 松本恵一：骨盤腔内腫疸患者に対する 督瘦および尿管瘦術：術前臨床検查值からみた適応の限界。 日泌尿会誌, $62 ： 58-63,1971$.

\title{
Report from an Urologic Clinic in Rural Area
}

\author{
Kimio Fujita, M.D.
}

In a year, from the beginning of my clinic on July 1972 until June 1973, 1,110 patients have visited; 628 were male and 482 were female. Males showed the tendency to retain hospital visit in spring and autumn when they are busy with farming. Out of 1,110 patients 71 were refered from doctors outside of the hospital, 346 were from other clinics in the hospital.

Diseases were classified following the International Classification of Disease. Simple cystitis, benign prostatic hypertrophy and upper urinary tract calculi were most frequent. 
Their, and also doctors who concerned, misunderstanding and ignorance of recent progress in urological management stimulated me to survey my experience and explain modern trends in the field. Urinary tract tuberculosis were sometimes considered as nonspecific chronic cystitis; ureteral stones were not recognized on $\mathrm{x}$-ray film; postrenal uremic state were confused with renal parenchymal failure. The value of pyelolithotomy in situ and transurethral resection were also stressed.

*Chief, Urological Division, Saku Central Hospital, Minamisaku Usuda, Nagano, Japan 